\title{
JUVENILE JUSTICE: ISSUES AND CHALLENGES
}

\author{
Dr.N.M.Khirale \\ Associate Professor \& Head, \\ Department of Law, Dr. Ambedkar College, \\ DeekshaBhoomi, Nagpur, \\ Maharashtra
}

Article DOI: https://doi.org/10.36713/epra3910

\begin{abstract}
'Children are the future of the nations and citizens of tomorrow, children are the asset of the country and must be protected from every lawful corner and developed as per the mandate of the constitution of India. The constitution of India dreams of a healthy society, and in furtherance of it has granted many rights to children. Chapters on fundamental rights and Directive principles laid down detailed provisions, Such as basic survival rights of life, development rights a regard to education, religion, cultural and freedom of thought, conscience and also protection rights from several kinds of abuses and exploitation.
\end{abstract}

KEYWORDS: juvenile, rights, care \& protection, judiciary

\section{INTRODUCTION}

A child under eighteen age who has been alleged or found to have committed an offence either Indian Penal code or under any law prescribing punishment is generally considered as Juvenile.in India large population of such children are increasing day by day, they need care and protection. The Juvenile Justice (Care and Protection of Children) Act 2000 clarified the concept of juvenile. 'The United Nations Convention on the Rights of the Child 1989 'has also specified but not clarified in its international documents.

The history of Juvenile justice legislation in India shows the types of neglected juvenile and juvenile delinquent. During the period of 80 years i.e. from 1920 to 2000 clear distinction was maintained between neglected juvenile and juvenile delinquent. There was no separate law for administration of justice for adult criminal and a juvenile offender. It was experienced also realized that children due to their immature mind are not capable of understanding the consequences of their act. So there developed the philosophy of separation of juvenile delinquent from the adult offender and in turn established separate administration of justice for juvenile delinquents.

The Reformatory Schools and the Industrial Schools were established in England. during the first decade of twentieth century, separate treatment to juvenile delinquent under the Reformatory Schools Act and to neglected juveniles under the Industrial Schools Act were provided.
The first juvenile court was established by America in the year 1899 and both the categories of children came to be dealt with by the juvenile court. England passed the Children Act of 1908 covering both the categories of children. India followed the pursuit and passed several Children Acts covering both the children together through sole legislation. The repealed Juvenile Justice Act 1986 and the present Juvenile Justice (Care and Protection of Children) Act 2015 covers both the categories of children. This inclusion of both the categories of children into sole legislation appears to be a major stumbling block in the effective implementation of the juvenile justice system in India.

\section{PROBLEM OF RESEARCH STUDY}

It is seen that there has been continuous experimentation in the juvenile justice system by making, amending, repealing and again making legislations and new policies. It is also the fact that the Supreme Court of India has laid down law for proper implementation of juvenile justice system from the year 1995. It is also the fact that despite of the Apex Court's intervention, the central government and the state governments have failed to implement even the major provisions of the Juvenile Justice Acts till passing of new Act of 2015.

The Supreme Court of India in Sheela Barse's case itself took the responsibility of monitoring the implementation of major provisions of Juvenile Justice Act, 
1986. The case was disposed of with certain directions in1995. In Sampurna Behrua's case, again the Supreme Court took the responsibility of monitoring the implementation (monitoring is still continue)of major provisions of the Juvenile Justice (Care and Protection of Children)Act, 2000. Despite of the Apex Court's intervention, the central government and the state governments have failed to implement the major provisions of the Juvenile Justice Act, 1986 (repealed) and Juvenile Justice (Care and Protection of Children) Act, 2000.Juvenile Justice Act, 2015

The ongoing failure of the juvenile justice system is admitted by the Ministry of Women and Child Development and the National Commission for Protection of Child Rights in the various reports published in their respective websites. The Sheela Barse's case and Sampurna Behrua's case also reflects the view of dismal status of implementation of the juvenile justice system.

The fact that the juvenile justice system in India is dysfunctional is proved beyond doubt. This led the investigator to form an opinion that there may be some stumbling blocks other than those researched out so far as to the cause of malfunctioning of juvenile justice system in India.

\section{HYPOTHESIS}

Ongoing failure of a system presupposes the ongoing existence of some stumbling blocks in the proper implementation itself. Therefore, this study adopts the hypothesis that there are some other major stumbling blocks in the effective implementation of juvenile justice system in India.

\section{SIGNIFICANCE OF STUDY}

A huge amount is being incurred in maintaining the structural requirement of juvenile justice system itself. What the children are getting is not known to them as well as to society. Beneficiaries appear to be the custodians of the juvenile justice system and not the children in the "system". In terms of Mr. V. Krishna Iyer,"the law which cannot be implemented is a satanic law and the same must be scrapped out." It must be clarified here that the investigator is not against the funding for care and protection of children but against the funding to maintain the bare structures of juvenile justice system. The proposed research study is directed to find out those major stumbling blocks to suggest reformations in the juvenile justice system. This is the significance of the study.

Keeping in view the nature and scope of the hypothesis, the conceptual and historical development of juvenile justice system in India, relevant national and international instruments on juvenile justice system, writings and reports of the eminent jurists and scholars in the field and judicial decisions, websites data will be examined in detail. May be some stumbling blocks other than those researched out so far as to the cause of malfunctioning of juvenile justice system in India.

\section{METHODOLOGY}

In this study, researcher has adopted the doctrinal research method.

\section{LIMITATION OF RESEARCH STUDY}

The research study is not intended to examine in detail the provisions of the juvenile justice legislations in India which developed through successive stages of history. The study is also intended to examine in detail the provisions of international instruments. This proposed study is intended to present the fact that the major provisions of juvenile justice system were substantially present in various Children Acts, the Children Act 1960, the Juvenile Justice Act 1986 and the Juvenile Justice (Care and Protection of Children) Act 2000.And the Juvenile Justice Act 2015.

\section{JUVENILE JUSTICE SYSTEM IN INDIA}

The juvenile justice system in India specially concentrates on welfare of child. The present system also laid down the procedure for controlling wrong / crimes committed by child below the age of 18 years. The juvenile justice law in relation to delinquent children in India focuses on the involvement in criminal offences; and power of police, rights of lawyers, and role of judges. In the present law provisions for children in need of care, some provisions for the welfare and modified justice are elaborately laid down but which are not adequate to give justice as per mandate of the Constitution. From the history of juvenile justice system particularly 1920 onwards in India. It is found that the term juvenile justice has been given different meanings in different contexts.

In its wider perspective it includes provisions for the welfare and wellbeing of all the children in need of care and protection, while the formal system of juvenile actually deals with those who are already in conflict with law or are likely to be so, for various reasons. It also implies fairness and justice towards juveniles in the political, social, and economic spheres. In criminological literature, juvenile justice connotes justice to the delinquent or near-delinquent child in various stages of the formal process such as arrest and apprehension, adjudication, sentencing, custodial care and detention, and after-care.

The term juvenile justice was sought to be clarified for the Sixth United Nations Congress on the Prevention of Crime and the Treatment of Offenders as follows

Juvenile justice after the onset of delinquency referred to justice in its normal juridical sense and that juvenile justice before the onset of delinquency referred to social justice. Thus, the concept of social justice was to be seen as relevant to the development of children and young persons generally and to endangered or adjudicated young 
offenders. The two were closely related but could be separated for purposes of discussion and training. The term Juvenile Justice is, therefore, used to refer to social as well as juridical justice. India seeks to provide social and juridical justice to neglected and delinquent children through the use of code, constables, court, and residential institutions for both categories of children, those committing an offence and others living in circumstances likely to lead them into a life of crime. Therefore, the juvenile justice system in India is neither fully civil nor fully criminal. It implies that if it is taken in the meaning of civil remedy then the juvenile who is alleged to have committed an offence will not have the rights of constitutional protection as available to an adult criminal. If it is taken in the sense of criminal remedy, then by applying the welfare principle, some of the rights of constitutional protection may be limited. In either of the way, the accused juvenile will not have the full rights of constitutional protection. From this point of view, juvenile justice system can be called as a hybrid system of justice.

First, if the juvenile justice system is viewed to provide a civil remedy, many of the rights that are protected by the Constitution in criminal cases becomes inapplicable because the remedy is to provide care and protection to the juvenile. Secondly, when the juvenile justice system is viewed to provide a punitive criminal remedy, many of the civil rights normally available to the juvenile may be limited. By limiting the rights of juveniles under both civil and criminal methodologies simultaneously however, the juvenile justice14system functions to give juveniles the worst of both worlds On the issue of implementation of juvenile justice system across the world, Gus Martin lamented in the following words There are many stories describing incompetence, mistreatment, corruption, and cover-ups within dysfunctional juvenile justice systems.

Investigations occasionally reveal criminal behavior within subsystems, such as troubling reports of beatings, neglect, or other inhumane treatment in correctional institutions. Poor implementation of Programmes by community-based organizations is not uncommon, and it is often the result of poor and incompetent oversight by government agencies- in other words, some problems are so blatant that even a cursory inspection would have revealed their deficiencies. Such problems and consequences pose ongoing challenges for the proper implementation of justice for juveniles.

The protection and promotion of human rights of children is not seen as a priority in the governance agenda, however, it is seen that the government is preoccupied of social and human rights movements as well as of social theory. The Supreme Court found its inability to enforce its directions against state governments and preferred to transfer the advocacy of juvenile justice system children to Supreme Court Legal Aid Committee. Human rightlessness is seen in everyday bureaucratic administration and judicial interpretation in the juvenile justice system. The government continuously violates the Constitutional and Internationally recognized human rights of the child. The democratic government, active judiciary and great human rights movements, all have simply failed to deliver a humane and just juvenile justice system. 
CRIME STATISTICS

EDUCATIONAL AND FAMILY BACKGROUND OF JUVENILES*ARRESTED UNDER IPC SPECIAL AND LOCAL LAWS

\begin{tabular}{|c|l|l|l|l|l|l|l|l|l|}
\hline \multicolumn{3}{|c|}{ By Education } & \multicolumn{3}{c|}{ By Family Background } \\
\hline Year & Illiterate & Primary & $\begin{array}{c}\text { Above } \\
\text { Primary } \\
\text { but } \\
\text { below } \\
\text { Matric/ } \\
\text { Hr.Sec. }\end{array}$ & $\begin{array}{c}\text { Matric/ } \\
\text { Higher } \\
\text { Sec.\& } \\
\text { above }\end{array}$ & Total & $\begin{array}{c}\text { Living } \\
\text { with } \\
\text { parents }\end{array}$ & $\begin{array}{c}\text { Living } \\
\text { with } \\
\text { guardians }\end{array}$ & Homeless & Total \\
\hline & $\mathbf{4}$ & $\mathbf{3}$ & $\mathbf{4}$ & $\mathbf{6}$ & $\mathbf{6}$ & $\mathbf{7}$ & $\mathbf{8}$ & $\mathbf{9}$ & $\mathbf{1 0}$ \\
\hline & & & & & & & & & \\
\hline 2001 & 7898 & 15943 & 7937 & 1850 & 33628 & 27020 & 4075 & 2533 & 33628 \\
\hline 2002 & 11323 & 13273 & 9350 & 1833 & 35779 & 27891 & 5692 & 2196 & 35779 \\
\hline 2003 & 9618 & 13505 & 7581 & 2616 & 33320 & 26435 & 4729 & 2156 & 33320 \\
\hline 2004 & 9273 & 10771 & 8848 & 2051 & 30943 & 23701 & 4922 & 2320 & 30943 \\
\hline 2005 & 8660 & 12394 & 9508 & 2119 & 32681 & 25398 & 4564 & 2719 & 32681 \\
\hline 2006 & 7975 & 12688 & 9405 & 2077 & 32145 & 24990 & 4958 & 2197 & 32145 \\
\hline 2007 & 7926 & 12659 & 10620 & 3322 & 34527 & 27074 & 5099 & 2354 & 34527 \\
\hline 2008 & 9069 & 12544 & 10072 & 2822 & 34507 & 27807 & 4852 & 1848 & 34507 \\
\hline 2009 & 7781 & 11653 & 10461 & 3747 & 33642 & 26633 & 4657 & 2352 & 33642 \\
\hline 2010 & 6339 & 11086 & 9855 & 3023 & 30303 & 24549 & 4082 & 1672 & 30303 \\
\hline 2011 & 6122 & 12803 & 10519 & 4443 & 33887 & 27577 & 4386 & 1924 & 33887 \\
\hline 2012 & 7226 & 13459 & 13983 & 5154 & 39822 & 31639 & 5793 & 2390 & 39822 \\
\hline 2013 & 8392 & 13984 & 15423 & 5812 & 43506 & 35244 & 5800 & 2462 & 43506 \\
\hline 2014 & 10530 & 15004 & 17637 & 5059 & 48230 & 38693 & 7905 & 1632 & 48030 \\
\hline 2015 & 4757 & 14229 & 19056 & 3343 & 41385 & 35448 & 4315 & 1622 & 41385 \\
\hline
\end{tabular}

Source: National Crime Records Bureau, Ministry of Home Affairs.

* As per revised definition of Juvenile Justice Act 2000, the boys in the age group 16-18 years have also been considered as Juveniles.

\section{FINDINGS}

1. India has been a country which has a large population of street children and who don't have families or has been neglected and no or poor education is responsible for breaking of the law by them.

2. From the above chart it is found that, In Last 10 years $(2005-2015)$ the illiterate rate is reduced from $8.66 \%$ to $4.75 \%$.

3. Rate of Primary education growth from $12.3 \%$ to $14.2 \%$.

4. Because of poverty and some more reasons, the rate of Primary to Higher secondary education, highly rises from $9.50 \%$ to $19.05 \%$.

5. Crime committed by Juvenile Age, between 16 to 18 is found to be $2.11 \%$ to $3.34 \%$.

6. Overall, Juveniles arrested under Indian Pinal Code and other social and local laws during 2005 to 2015 , i.e. highly growth from $32.6 \%$ to $41.3 \%$ it means in totality the rate of commission of crime by Juvenile because of non-viability of proper education is found to be $8.7 \%$.
7. Considering Family Background of Juvenile the percentage of commission of crime is found to be $32.68 \%$ to $41.38 \%$ intotallity the rate of commission of crime by Juvenile because of non-viability of proper family background is found to be $8.7 \%$.

8. India has been a country which has a poor education, large population neglected alone street is responsible for breaking of the law by them.

9. There is ongoing failure of juvenile justice system in India. effective implementation, coordination, monitoring, and accountability under present law has created uncertainty in the administration of juvenile justice. juvenile in conflict with law and children in need of care and protection together for the purpose of providing care, protection and treatment through sole legislation has to be amended in the spirit of the constitutional mandate.

\section{SUGGESTIONS AND CONCLUSIONS}

The rapid growth of technology and access to anything within fingertips changing the mentality of the children contributing in committing certain dreadful crimes 
by the children below the age of 18 years. The government, NGO, schools/college administrations, teachers and parents collectively find out the ways to protect them from evil influences of mobiles, T.V channels, Internet, and adult movies.If juveniles are prosecuted and punished for commission of crimes, like the adults in such tender age the probability of them turning into hardened criminals is possible so, there is need of special protection and care, as they are future of the country.

\section{REFERENCES}

1. Ved Kumari, The Juvenile Justice System in India: From Welfare to Rights, p.89 (OxfordUniversity Press, New Delhi, 2nd edn.,2010)

2. K.F. Rustamji, 'Note on Legal Measure Relating to Social Defence (Child)-Supportive Measures Needed for Their Effective Enforcement', a paper presented at the Workshop on National Children's Act, sponsored by SOS Children's Villages, Multiple Action Research Group, Joint Women's Programme, Community Aid and Sponsorship Programme, and the Indian Social Institute, held at the Indian Social Institute, New Delhi, 10 August 1986

3. Sheela Barse v. Union of India, AIR 1986 (SC) 1773

4. Gus Martin, Juvenile Justice: Process and Systems, p.4 (Sage Publications, USA, 2005)

5. JGus Martin, Juvenile Justice: Process and Systems, p.365 (Sage Publications, USA, 2005)

6. [S.P. Srivastava, Juvenile Justice in India Programmes and Perspectives, 4(1989)].

7. 'Juvenile Justice: Before and After the Onset of Delinquency', working paper prepared by the Secretariat, Sixth UN Congress on the Prevention of Crime and the Treatment of Offenders, Caracas, Venezuela, p.6 (25 August to 5 September 1980), A/CONF.87/5, 4 June 1980), cited in Ved Kumari, The Juvenile Justice System in India: From Welfare to Rights, Oxford University Press,2ndEdn., 2010, p.2

8. Upendra Baxi Foreword to the Book 'The Juvenile Justice System in India:' From Welfare to Rights by Ved Kumari

9. https:/www.legalbites.in/juvenile-justice-act-anoverview-and-new-challenge-to-it/ visited on 12/8/2018]

10. https://blog.ipleaders.in/juvenile-justice-system-indial visited on 09-01-2020]

11. https://shodhganga.inflibnet.ac.in/bitstream/10603/1409 52/8/08 visited on 09-01-2020 